\title{
Protective Effects of Melatonin on Spinal Cord Injury
}

\author{
Efectos Protectores de la Melatonina en Lesión de la Médula Espinal
}

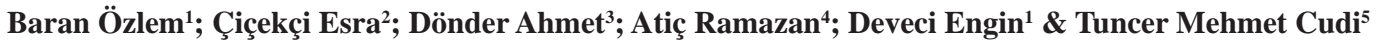

BARAN, Ö.; ÇIÇEKÇI, E.; DÖNDER, A.; ATIÇ, R.; DEVECI, E. \& TUNCER, M. C. Protective effects of melatonin on spinal cord injury. Int. J. Morphol., 36(2):488-492, 2018.

SUMMARY: Spinal cord injury causes neuron nerve fiber loss. The aim of this study was to investigate the neuroprotective, inflammatory and angiogenetic effects of melatonin on rat spinal cord injury (SCI). For spinal cord injury, a standard weight reduction method was used that caused moderate severity of injury ( $100 \mathrm{~g} / \mathrm{cm}$ force $)$ att 10 Melatonin $(10 \mathrm{mg} / \mathrm{kg}$ intraperitoneally $)$ was dministered for 10 days after trauma. Each group consisted of 10 animals. of these, six were used for biochemical and four were used for the e evaluation of histological analysis. Spinal cord samples were taken for histological examination or determination of malondiald ehyde (MDA) and glutathione (GSH) levels, myeloperoxidase (MPO) activity Spinal cord injury and melatonin treated group were compare. Melatonin administration in spinal cord injury increased the activity of glial cells in the radial and funicular cells and epen dymal cells and increased the activity of glial cells and also showed a positive ef fect on inflammation and vascular endothelial cells in $\mathrm{s}$ ynaptic connections in the nerve fibers undegoing spinal injury endothelial degeneration It is thought that it can regulate the degenerative effect which is caused by both the inflammatory effect and the angiogenic effect which will have a positive effect on the neural connection.

KEY WORDS: Spinal cord injury; Melatonin; TNF- $\alpha$; Endothelin-1.

\section{INTRODUCCIÓN}

Spinal cord injury (SCI) can result in severe disability, sensory disorder, paralysis, other neurologic deficits and even death (Samantaray et al., 2008). SCI usually begins with a sudden, traumatic blow to the spine that fractures or dislocates vertebrae. Long-term mechanical compression of the spinal cord gradually causes various pathologic changes in neural tissue, such as reduced activity of surviving neuronal cells, neuronal degeneration, and demyelination of axons (Inukai et al., 2009).

Melatonin which is the main secrebry body of pineal gland is believed to be an important part in sleep/wake cycle regulation and also the sleep disorder in old age people (AlAama et al., 2011). The biological clock in the hypothalamic suprachiasmatic nucleus $(\mathrm{SCN})$ regulates melatonin secretion by the pineal gland as well as circadian rhythm regulation (Asayama et al., 2003).There are a number of studies where melatonin has been shown to regulate various physiological functions in the body such as immune enhancing, anti-inflammatory properties (Esposito \& Cuzzocrea, 2010), radicals scavenger (Galano et al., 2011), traumatic CNS injury (Samantaray et al., 2009). TNF- $\alpha$ is an acute-phase protein that initiates a cascade of cytokines and increases vascular permeability, thereby recruiting macrophage and neutrophils to the site of infection (Esposito \& Cuzzocrea, 2009). After SCI, TNF-a levels become elevated in the spinal cord, reaching a ped within $1 \mathrm{~h}$ after the initial trauma (Dinomais et al., 2009).

The pathophysiology of SCI is thought to include two stages: primary injury and secondary injury which is mediated by multiple injury processes including inflammation, autoimmune response, vascular events, apoptosis, free radical-induced cell death, and glutamate excitotoxicity (Khalatbary \& Ahmadvand, 2011). The protective effect of Melatonin on neuronal and angiogenetic function after medulla spinalis injury was investigated.

\footnotetext{
${ }^{1}$ Department of Histology and Embryology, Dicle University School of Medicine, Diyarbakir, Turkey.

${ }^{2}$ Department of Physiotheraphy, Diyarbakir Gazi Yasargil Education and Research Hospital, Diyarbakir, Turkey.

${ }^{3}$ Ataturk Health High School, Dicle University, Diyarbakir, Turkey.

${ }^{4}$ Department of Orthopaedic and Traumatology, Faculty of Medicine, University of Dicle, Diyarbakir, Turkey.

${ }^{5}$ Department of Anatomy, Dicle University School of Medicine, Diyarbakir, Turkey.
} 


\section{MATERIAL AND METHOD}

The investigation was conducted in accordance with the Guide for the Care and Use of Laboratory Animals published by US National Institutes of Health (NIH Publication no. 85-23, revised 1996). All experimental protocols were approved by the Dicle University Animal Care and Use Committee. Male Sprague-Dawley rats (200$230 \mathrm{~g}$ ) were housed in an air -conditioned room with $12-\mathrm{h}$ light and dark cycles, where the temperature $\left(23 \pm 2{ }^{\circ} \mathrm{C}\right)$ and relative humidity $(65-70 \%)$ were kept constant.

Anesthetized (intrapertoneally ketamine and chlorpromazine; $75 \mathrm{mg} / \mathrm{kg}$ and $1 \mathrm{mg} / \mathrm{kg}$, respectively) rats were positioned on a heating pad in a prone position and a rectal probe was inserted. Under sterile conditions, following T5-12 midline skin incision and paravertebral muscle dissection, spinous processes and laminar arcs ofl7-10 were removed. The dura was left intact. Weight-drop model was performed for SCI (Allen, 1911). The animals were subjected to an impact of $100 \mathrm{~g} / \mathrm{cm}$ to the dorsal surface of the spinal cord. The force was applied via a stainless steel $\operatorname{rod}(3 \mathrm{~mm}$ diameter tip weighing $10 \mathrm{~g}$ ) that was rounded at the surface. The rod was dropped vertically through a $10-\mathrm{cm}$ guide tube that was positioned perpendicular to the center of the spinal cord. Afterward, the muscles and the incision were sutured. Following surgical procedure, the rats were placed in warming chamber and their body temperatures were maintained at approximately $37{ }^{\circ} \mathrm{C}$ until they were completely awake (spinal kord-gonoderma referans). Melatonin (10 mg/kg intraperitoneally) was administered for 10 days after trauma Each group consisted of 10 animals. of these, six of them were used for biochemical and other four were used for the evaluation of histological analysis (Table I).

Histological Preparation and Analysis At the end of the experiment, all animals were anesthetized via the intraperitoneal administration of ketamine HCL $(0.15 \mathrm{ml} /$ $100 \mathrm{~g}$ body weight). The spinal cords were dissected. For the histological examination, spinal cords tissues were fixed in $10 \%$ formaldehyde solution, post fixed in $70 \%$ alcohol, and embedded in paraf fin wax. The sections were stained with Hematoxylin-Eosin.

Immunohistochemical staining. An antigen-retrieval process was performed in citrate buf fer solution ( $\mathrm{pH}$ 6.0) two times: first for $7 \mathrm{~min}$, and then for $5 \mathrm{~min}$ in a microwave oven at $700 \mathrm{~W}$. They were allowed to cool to room temperature for $30 \mathrm{~min}$ and washed in distilled water for 5 min twice. Endogenous peroxidase activity was blocked in $0.1 \%$ hydrogen peroxide for $15 \mathrm{~min}$. Ultra V block (Histostain-Plus Kit, Invitrogen, Carlsbad, CA) was applied for 10 min prior to the application of the primary antibodies (Tumor Necrosis Factor-Alpha(TNF- $\alpha$ )and Endothelin-1 antibodies, mouse monoclonal,1/200, Santa Cruz Biotechnology) overnight. The secondary antibody (Histostain-Plus Kit, Invitrogen,Carlsbad, CA) was applied for $20 \mathrm{~min}$. Then the slides were exposed to streptavidinperoxidase for $20 \mathrm{~min}$. Diaminobenzidine (DAB, Invitrogen, Carlsbad) was used as a chromogen. Control slides were prepared as mentioned above but omitting the primary antibodies. After counterstaining with hematoxylin, washing in tap water for $5 \mathrm{~min}$, and in distilled water for $2 \times 5 \mathrm{~min}$, the slides were mounted.

Measurement of MPO Activity. Spinal cord tissue samples were homogenized in $50 \mathrm{mM}$ potassium phosphate buf fer with a $\mathrm{pH}$ of 6.0 , and centrifuged at $41,400 \mathrm{~g}$ for $10 \mathrm{~min}$. The pellets were then suspended in $50 \mathrm{mM}$ PB containing $0.5 \%$ hexa-decyl trimethyl-ammonium bromide (HETAB). After three freeze and thaw cycles, with sonication between cycles, the samples were centrifuged at 41,400 g for 10 minAliquots $(0.3 \mathrm{ml})$ were added to $2.3 \mathrm{ml}$ of reaction mixture containing $50 \mathrm{mM}$ PB, o-dianisidine, and $20 \mathrm{mM} \mathrm{H}_{2} \mathrm{O}_{2}$ solution. One unit of enzyme activity was defined as the amount of MPO present that caused a change in absorbance, measured at 460 $\mathrm{nm}$ for $3 \mathrm{~min}$. MPO activity was expressed as $\mathrm{U} / \mathrm{g}$ tissue.

Malondialdehyde (MDA) and Glutathione (GSH) Assays. Spinal cord tissue samples were homogenized with ice-cold $150 \mathrm{mMKCl}$ for the determination of MDA and GSH levels.

Table I. Biochemical results relevant to the study groups.

\begin{tabular}{lcccc}
\hline & Control & Melatonin & Spinal cord injury & Spinal cord injury + G. lucidum \\
\hline MDA $(\mathrm{nmol} / \mathrm{g})$ & $26.8 \pm 0.88$ & $26.12 \pm 0.82$ & $42.93 \pm 0.73^{* * *}$ & $28.27 \pm 0.77+++$ \\
GSH $(\mu \mathrm{mol} / \mathrm{g})$ & $1.54 \pm 0.02$ & $1.65 \pm 0.02^{*}$ & $0.72 \pm 0.05^{* * *}$ & $1.38 \pm 0.03+++$ \\
MPO $(\mathrm{U} / \mathrm{g})$ & $3.39 \pm 0.04$ & $3.43 \pm 0.03$ & $8.14 \pm 0.71^{* * *}$ & $7.63 \pm 0.42^{++}$ \\
\hline
\end{tabular}

Values are represented as mean $\pm \mathrm{SD}$. Each group consists of sixteen rats. $* \mathrm{p}<0.05$, versus control $* * * \mathrm{p}<0.001$, versus Spinal cord injury . $++\mathrm{p}<0.01$, Spinal cord injury + G. lucidum versus trauma. $+++\mathrm{p}<0.001$, trauma + G. lucidum versus trauma. 
The MDA levels were assayed for the products of lipid peroxidation and results are expressed as nmol MDA/g tissue GSH was determined by a spectrophotometric method based on the use of Ellman's reagent and results are expressed as $\mathrm{mmol} \mathrm{GSH} / \mathrm{g}$ tissue

Statistical Analysis. All data are expressed as means \pm S.D. Groups of data were compared with an analysis of variance (ANOVA) followed by Tukey's multiple comparison tests. Values of $p<0.05$ were considered as significant.

\section{RESULT AND DISCUSSION}

MPO activity, which is accepted as an indicator of neutrophil infiltration, was higher in the spinal cord tissues of traumatic rats than those of the control group $(p<0.001)$. Melatonin treatment significantly decreased spinal cord tissue MPO levels $(\mathrm{p}<0.01)$.

Trauma caused a significant increase in the MDA levels $(p<0.001)$ with a concomitant decrease in GSH levels $(p<0.001)$. Melatonin treatment significantly reduced the increase in MDA levels and restored GSH content at seventh day.

In the study it was concluded that melatonin treatment was ef fective in reducing the activation of inflammation and tissue injury in an animal model of spinal cord injury (Genovese et al., 2005). The antioxidant properties of melatonin are connected with its neuroprotective activity in several degenerative disorders. One of the causes of neurodegenerative damage in the nervous system is oxidative injury, which results from an imbalance between free radical formation and antioxidative mechanisms (Emerit et al., 2004).

Reactive astrocytes also play a crucial role in wound healing and functional recovery after SCIAt the subacute phase, astrocytes migrate to compact the lesion, presumably secluding the inflammatory cells to prevent them from spreading into the parenchyma of the spinal cord (Okada et al., 2006). In our study, when spinal cord injury and melatonin group were compared, ependymal cells showed regular distribution around the canalis centralis, mild hypertrophy in the cells and intense and regular distribution of nerve fibrils in the bipolar appearance of the funicular cells. TNF- $\alpha$ expression was found to be positive in some funicular cells and glial cells, whereas TNF- $\alpha$ expression was more prominent in some nerve endings. It is thought that melatonin may be ffetive on the inflammation reaction due to the positive TNF- $\alpha$ expression in the melatonin group. Our data show that Endothelin-1 expression in glial cells and endothelial cells is increased in spinal cord injury (Fig. 1b), but Endothelin1 expression in neuron and endothelial cells is decreased in spinal cord injury of melatonin treatment. Melatonin administration in spinal cord injury increased the activity of glial cells in the radial and funicular cells, and ependymal cells and increased the activity of glial cells; it also showed a positive ef fect on inflammation and vascular endothelial cells, in synaptic connections in the nerve fibers under going spinal injury endothelial degeneration. It is thought that it can regulate the degenerative effect which is caused by both the inflammatory effect and the angiogenic effect which will have a positive effect on the neural connection.

BARAN, Ö.; ÇIÇEKÇI, E.; DÖNDER, A.; ATIÇ, R.; DEVECI, E. \& TUNCER, M. C. Efectos protectores de la melatonina en lesión de la médula espinal.Int. J. Morphol., 36(2):488-492, 2018

RESUMEN: La lesión de la médula espinal (SCI) provoca daño en la fibra nerviosa, que puede conducir a alteraciones motoras y sensitivas, incluso la muerte. El objetivo de este estudio fue investigar los efectos neuroprotectores, proinflamatorios y proangiogénicos de la melatonina en un modelo de SCI inducida en rata. Para tal efecto se utilizaron dos grupos: Grupo 1 (n:10) se le indujo una SCI, mediante el método de reducción de peso estándar (100 g/cm fuerza), provocando una lesión de severidad moderada. Grupo 2 (n:10) inducción SCI más aplicación de T10 Melatonina (10 mg / kg vi.) durante 10 días después del trauma. Muestras de seis animales de cada grupo fueron usados para análisis bioquímicos y los otros cuatro para la evaluación histológica. Se tomaron muestras de médula espinal para el examen histológico y para la determinación de niveles de malondialdehído (MDA) y glutatión (GSH), actividad mieloperoxidasa (MPO) y se comparó la lesión de la médula espinal y el grupo tratado con melatonina. La administración de melatonina en la lesión de la médula espinal aumentó la actividad de las células gliales en las células radiales, funiculares y ependimocitos.Ademas mostró un efecto positivo sobre la inflamación y angiogénesis en las conexiones sinápticas en las fibras nerviosas sometidas a lesión espinal. Pudiendo este participar en la regulación del efecto degenerativo causado, principalmente, por acción de angiogénesis e inflamación local.

PALABRAS CLAVE: Lesión medula espinal; Melatonina; TNF- $\alpha$; Endothelin-1. 

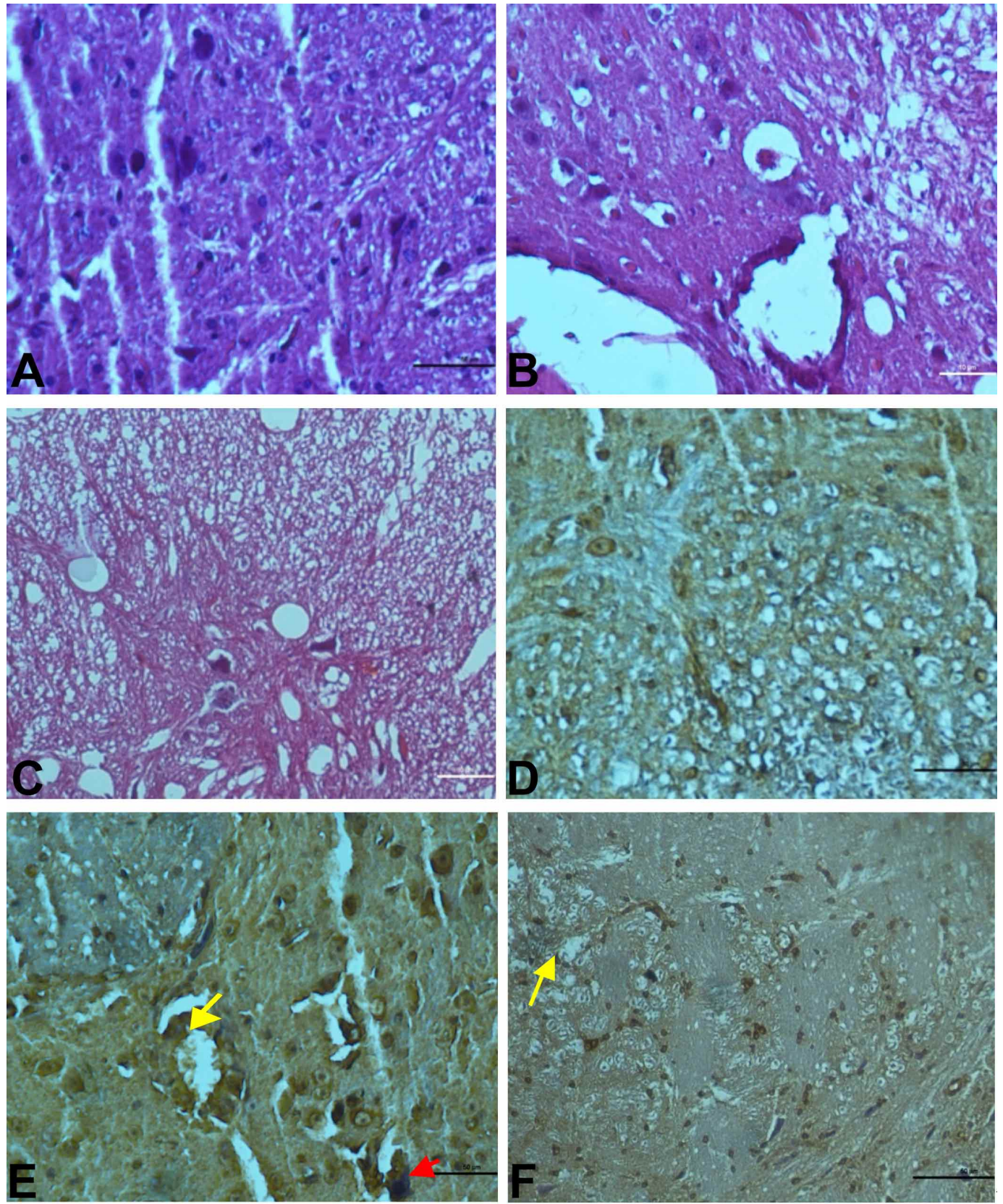

Fig. 1. A.- Control group: Cornu anterior covered with oval nucleus cubic-shaped epithelium,multipolar neuron structures and glial cells in the fissura mediana anterior region were regularly observed. H-E staining Bar $100 \mu \mathrm{m}$, B.-Spinal cord injury group: Degeneration and picnosis in Canalis ependimalis cells, vacuolization in some radical cells (arrow), hyperplasia in funicular cells, dilatation in small capillary vessels, necrosis in the area of substantia grisea were observed. HE staining Bar $100 \mu \mathrm{m}$, C.- Spinal cord injury+Melatonin group: Ependymal cells showed regular

distribution around the canalis centralis, mild hypertrophy in the cells

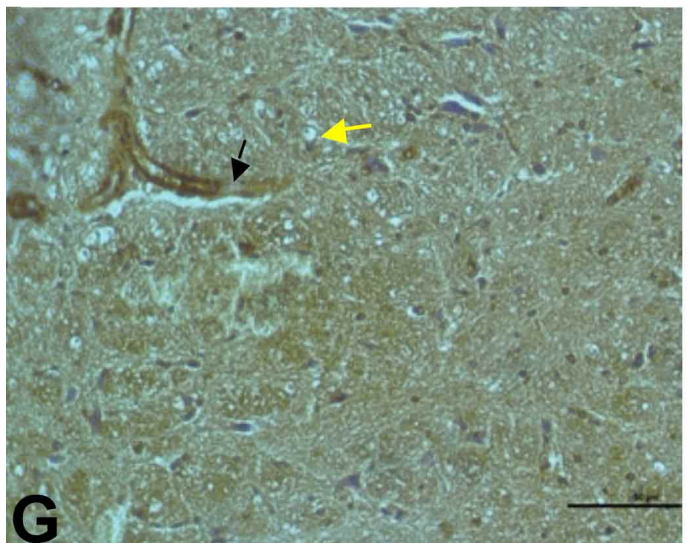

and intense and regular distribution of nerve fibrils in the bipolar appearance of the funicular cells. HE staining Bar 10qum, D.- Spinal cord njury group:TNF$\alpha$ expression is positive in ependymal cells, TNF- $\alpha$ expression is positive in glial cells and radicular cells. TNF- $\alpha$ immunstaining Bar $50 \mu \mathrm{m}$, E.- Spinal cord injury+Melatonin group: TNF- $\alpha$ expression was found to be positive in some funicular cells and glial cells, whereas TNF- $\alpha$ expression was more prominent in some nerve endings.TNF- $\alpha$ immunstaining Bar $50 \mu \mathrm{m}$, F.- Spinal cord nnjury group: Positive endothelin expression in radicular cells, glia cells and vascular endothelium (arrow) Endothelin-1 immunostaining staining Bar $100 \mu \mathrm{m}$, G.- Spinal cord injury+Melatonin group:Weak Endothelin-1 expression was seen in glial cells and vascular endothelial cells. VEGF immun-staining staining Bar $100 \mu \mathrm{m}$. 


\section{REFERENCES}

Al-Aama, T.; Brymer, C.; Gutmanis, I.; Woolmore-Goodwin, S. M.; Esbaugh, J. \& Dasgupta, M. Melatonin decreases delirium in elderly patients: a randomized, placebo-controlled trial. Int. J. Geriatr. Psychiatry, 26(7):687-94, 2011.

Allen, A. R. Sur gery of experimental lesion of spinal cord equivalent to crush injury of fracture dislocation of spinal column. A preliminary report. JAMA, 57(11):878-80, 1911.

Asayama, K.; Yamadera, H.; Ito,T.; Suzuki, H.; Kudo,Y. \& Endo, S. Double blind study of melatonin effects on the sleep-wake rhythm, cognitive and non-cognitive functions in Alzheimer type dementia. J. Nippon Med. Sch., 70(4):334-41, 2003.

Dinomais, M.; Stana, L.; Egon, G.; Richard, I. \& Menei, P . Significant recovery of motor function in a patient with complete $\mathrm{T} 7$ paraplegia receiving etanercept. J. Rehabil. Med., 41(4):286-8, 2009.

Emerit, J.; Edeas, M. \& Bricaire, F . Neurodegenerative diseases and oxidative stress. Biomed. Pharmacother., 58(1):39-46, 2004.

Esposito, E. \& Cuzzocrea, S. Antiinflammatory activity of melatonin in central nervous system. Curr. Neuropharmacol., 8(3):228-42, 2010.

Esposito, E. \& Cuzzocrea, S. TNF-alpha as a therapeutic tar get in inflammatory diseases, ischemia-reperfusion injury and trauma. Curr. Med. Chem., 16(24):3152-67, 2009.

Galano, A.; Tan, D. X. \& Reiter, R. J. Melatonin as a natural ally against oxidative stress: a physicochemical examination.J. Pineal Res., 51(1):1$16,2011$.

Genovese, T.; Mazzon, E.; Muià, C.; Bramanti, P .; De Sarro, A. \& Cuzzocrea, S. Attenuation in the evolution of experimental spinal cord trauma by treatment with melatonin. J. Pineal Res., 38(3):198-208, 2005 .

Inukai, T.; Uchida, K.; Nakajima, H.; Yayama, T.; Kobayashi, S.; Mwaka, E. S.; Guerrero, A. R. \& Baba, H. Tumor necrosis factor-alpha and its receptors contribute to apoptosis of oligodendrocytes in the spinal cord of spinal hyperostotic mouse (twy/twy) sustaining chronic mechanical compression. Spine (Phila Pa 1976), 34(26):2848-57, 2009.

Khalatbary, A. R. \& Ahmadvand, H. Anti-inflammatory effect of the epigallocatechin gallate following spinal cord trauma in rat. Iran. Biomed. J., 15(1-2):31-7, 2011.

Okada, S.; Nakamura, M.; Katoh, H.; Miyao, T.; Shimazaki, T.; Ishii, K.; Yamane, J.; Yoshimura, A.; Iwamoto, Y.; Toyama, Y. \& Okano, H. Conditional ablation of Stat 3 or Socs 3 discloses a dual role for reactive astrocytes after spinal cord injury. Nat Med., 12(7):829-34, 2006.

Samantaray, S.; Das, A.; Thakore, N. P.; Matzelle, D. D.; Reiter R. J.; Ray, S. K. \& Banik, N. L. Therapeutic potential of melatonin in traumatic central nervous system injury. J. Pineal Res., 47(2):134-42, 2009.

Samantaray, S.; Sribnick, E. A.; Das, A.; Knaryan, V. H.; Matzelle, D. D.; Yallapragada, A. V.; Reiter, R. J.; Ray, S. K. \& Banik, N. L. Melatonin attenuates calpain upregulation, axonal damage and neuronal death in spinal cord injury in rats. J. Pineal Res., 44(4):348-57, 2008.

\author{
Corresponding author: \\ Dr. Engin Deveci \\ Department of Histology and Embryology \\ Dicle University Faculty of Medicine \\ Diyarbakir \\ TURKEY
}

Email: engindeveci64@gmail.com

Received: 11-09-2017

Accepted: 02-01-2018 